\title{
PEMBERDAYAAN DAN PARTISIPASI MASYARAKAT PESISIR DALAM PENGEMBANGAN TANAMAN MANGROVE DI KABUPATEN PATI
}

\author{
EMPOWERMENT AND COASTAL COMMUNITY PARTICIPATION \\ ON MANGROVE DEVELOPMENT IN PATI REGENCY
}

\author{
Sutrisno \\ Kantor Penelitian dan Pengambangan Kab. Pati \\ Email: trisno_1201@yahoo.com \\ Dikirim: 1 Desember 2014 Direvisi: 10 Januari 2015 Disetujui: 20 Februari 2015
}

\begin{abstract}
Abstrak
Pengembangan tanaman mangrove merupakan usaha yang sangat komplek untuk dilaksanakan, karena kegiatan tersebut sangat membutuhkan sifat akomodatif masyarakat sekitar pesisir. Penelitian ini bertujuan untuk mengetahui peranan pemerintah dalam pemberdayaan masyarakat pesisir dan partisipasi masyarakat pesisir dalam pengembangan tanaman mangrove di Kabupaten Pati. Metode penelitian menggunakan deskriptif dengan sumber data primer berasal dari survei terhadap 282 responden petani yang terlibat langsung dalam kegiatan pengembangan tanaman mangrove, data sekunder diambil dari dokumen yang relevan, adapun analisis data menggunakan deskriptif. Hasil penelitian menunjukkan: (1) Peranan pemerintah terhadap pemberdayaan masyarakat pesisir dalam pengembangan tanaman mangrove memperoleh skor rata-rata 49,94 termasuk kategori cukup, (2) Partisipasi masyarakat dalam pengembangan tanaman mangrove memperoleh skor rata-rata 41,81 termasuk kategori cukup.
\end{abstract}

Kata kunci: Pemberdayaan, partisipasi, masyarakat pesisir, mangrove

\begin{abstract}
Development of mangrove plants is a very complex effort to implement, because the activity needs accommodative nature of the community around the coastal. This study aims to determine the government's role in the empowerment of coastal communities and public participation in the development of coastal mangrove plant in Pati regency. The research used descriptive approach with primary data was obtained from survey toward 282 respondents whom directly involved in mangrove development, while secondary data were obtained from relevant documents. The data were analyzed using descriptive method. The results of research are: (1) The score of government's role on coastal community empowerment and mangrove development is 49.94 (categorized as enough). (2) Community empowerment on mangrove development get score 41.81 (categorized as enough)
\end{abstract}

Keywords: empowerment, participation, coastal community, mangrove

\section{PENDAHULUAN}

Indonesia merupakan negara kepulauan dengan jumlah pulau mencapai 17.508 dan panjang garis pantai $\pm 81.000 \mathrm{~km}$ (Departemen Kelautan dan Perikanan dalam Manaf, 2013). Salah satu daerah yang memiliki garis pantai adalah Kabupaten Pati Provinsi Jawa Tengah yaitu sepanjang $\pm 60 \mathrm{~km}$ (DepHut, 2006). Garis pantai Kabupaten Pati melintasi 7 kecamatan yaitu Dukuhseti, Tayu, Margoyoso, Trangkil, Wedarijaksa, Juwana dan Batangan. Secara umum, wilayah pesisir dapat didefinisikan sebagai daerah peralihan antara ekosistem darat dan laut yang dipengaruhi oleh perubahan di darat dan laut (UU No. 27 Tahun 2007). Keadaan ini menyebabkan wilayah pesisir menjadi salah satu andalan sumber pendapatan Kabupaten Pati.

Transisi antara daratan dan lautan di wilayah pesisir telah membentuk ekosistem yang beragam dan sangat produktif, serta memberikan nilai ekonomi yang luar biasa terhadap kehidupan manusia. Sejalan dengan pertambahan penduduk dan peningkatan kegiatan pembangunan sosial ekonomi, "nilai” wilayah pesisir terus bertambah. Konsekuensi dari tekanan terhadap pesisir ini adalah masalah pengelolaan yang timbul karena konflik pemanfaatan akibat berbagai kepentingan yang ada di wilayah pesisir (Nurmalasari, 2001).

Wilayah pesisir pada dasarnya tersusun dari berbagai macam ekosistem (mangrove, terumbu karang, estuaria, pantai berpasir dan lainnya) yang satu sama lain saling berkait dan tidak berdiri sendiri. Perubahan atau kerusakan yang menimpa satu ekosistem akan menimpa ekosistem lainnya. Selain itu wilayah pesisir juga dipengaruhi oleh berbagai macam kegiatan manusia maupun proses-proses alamiah yang terdapat di lahan atas (upland areas) maupun laut lepas (oceans). Kondisi empiris semacam ini mensyaratkan dalam melakukan pengelolaan pesisir dan lautan harus memperhatikan 
segenap keterkaitan ekosistem yang dapat mempengaruhi perubahan suatu wilayah pesisir.

Memperhatikan kondisi kawasan pesisir sepanjang $\pm 60 \mathrm{~km}$ dari ujung utara Kecamatan Dukuhseti sampai ujung timur Kecamatan Batangan Kabupaten Pati, kondisi tanaman mangrove secara umum masih memprihatinkan, hal ini dapat dilihat dari penanaman baru 16,07 Ha (6,72 \%), tanaman mangrove dalam kondisi hidup baik 155,93 ha (65,24 \%), dan tanaman rusak 67 На (28,03 \%), sehingga jumlah total tanaman mangrove dikawasan pesisir Kabupaten Pati yang membentang di 7 Kecamatan hanya 239 Ha (Dislautkan Kab. Pati, 2013).

Untuk meminimalisir dampak yang lebih besar lagi terhadap tekanan sumber daya mangrove, maka diperlukan pemberdayaan masyarakat pesisir yang dilakukan secara intensif sehingga dapat menjadikan masyarakat sebagai komponen utama penggerak partisipasif dalam pengembangan tanaman mangrove. Begitu pula sebaliknya rendahnya pemahaman masyarakat terhadap fungsi dan peranan tanaman mangrove dapat menyebabkan makin menurunnya daya dukung lingkungan sumberdaya pesisir dan kualitas hidup komunitas penduduk setempat.

Pengembangan tanaman mangrove merupakan usaha yang sangat komplek untuk dilaksanakan, karena kegiatan tersebut sangat membutuhkan sifat akomodatif masyarakat sekitar kawasan pesisir. Namun demikian sifat akomodatif ini akan lebih dirasakan manfaatnya bilamana keberpihakan terhadap masyarakat pesisir yang sangat rentan terhadap sumberdaya mangrove diberikan porsi yang lebih besar. Menurut Sembiring dan Husbaini (1999), pemberian porsi yang besar kepada masyarakat pesisir harus diiringi dengan upaya membangun kesadaran dan persepsi pentingnya arti dan peran hutan mengrove itu sendiri. Pandangan masyarakat pesisir selama ini hanya melihat kepentingan tanaman mangrove dari sudut ekonomi, secara berangsur-angsur digiring kearah kepentingan bioekologi.

Kusmana (1995) menyatakan bahwa fungsi hutan mangrove dibagi atas tiga yaitu: (1) fungsi fisik, dapat melindungi lingkungan dari pengaruh oseanografi (pasang surut, arus, angin topan, dan gelombang), mengendalikan abrasi dan mencegah intruisi air laut ke darat; (2) fungsi biologi, sangat berkaitan dengan perikanan yaitu sebagai daerah asuhan (nursery ground), daerah mencari makan (feeding ground), dan daerah pemijahan (spawning ground) dari beberapa jenis ikan dan udang, serta merupakan penyuplai unsur-unsur hara utama di pantai khususnya daerah lamun dan terumbu karang; (3) fungsi ekonomi, sebagai sumber kayu kelas satu, bubur kayu, bahan kertas, chips, dan arang.

Kurangnya proses yang akomodatif dalam pemberdayaan masyarakat pesisir terhadap tanaman mangrove dapat menyebabkan tingkat partisipasi masyarakat pesisir yang rendah dalam melalukan pelestarian dan rentan terhadap kerusakan tanaman mangrove. Akibat dari kurangnya pemahaman ini masyarakat pesisir lebih banyak mengusahakan tanaman mangrove untuk kegiatan usaha yang mempunyai dampak secara langsung dalam memenuhi kebutuhan hidup seperti pertambakan, pertanian dan kurang memperhatikan pengelolaan tanaman mangrove berkelanjutan sehingga tanaman mangrove tidak tumbuh dan berkembang dengan baik. Berdasarkan latar belakang tersebut, maka rumusan permasalahan penelitian ini adalah bagaimana peranan pemerintah dalam pemberdayaan masyarakat pesisir dan bagaimana partisipasi masyarakat pesisir dalam pengembangan tanaman mangrove di Kabupaten Pati. Adapun tujuan penelitian ini adalah untuk mengetahui peranan pemerintah dalam pemberdayaan masyarakat pesisir dan partisipasi masyarakat pesisir dalam pengembangan tanaman mangrove di Kabupaten Pati.

\section{METODE}

Lokasi penelitian dilaksanakan di Kabupaten Pati, meliputi 7 Kecamatan dari 21 Kecamatan (33,33 \%) yaitu Kecamatan Dukuhseti, Tayu, Margoyoso, Trangkil, Wedarijaksa, Juwana dan Batangan dengan pertimbangan bahwa wilayah tersebut merupakan wilayah pesisir yang merupakan tempat aktivitas pengembangan tanaman mangrove. Adapun waktu pelaksanaan penelitian dilakukan pada bulan April sampai dengan bulan Agustus 2013.

Penelitian ini menggunakan metode deskriptif. Menurut Nasir (2003) metode deskriptif bertujuan untuk membuat deskripsi, gambaran atau lukisan secara sistematis, faktual dan akurat mengenahi fakta-fakta, sifat-sifat serta hubungan antar fenomena yang diselidiki. Jumlah sampel ditemukan berdasarkan besarnya jumlah petani yang terlibat langsung dalam aktivitas pengembangan tanaman mangrove di Kabupaten Pati yang memenuhi penstrataan dengan tingkat kesalahan 5 \%. Formulasi untuk menentukan jumlah sampel dalam penelitian ini dengan menggunakan formulasi Krecjie (Sugijono, 1999). Krecjie dalam melakukan perhitungan ukuran sampel didasarkan atas kesalahan $5 \%$, sehingga sampel yang diperoleh mempunyai kepercayaan $95 \%$ terhadap populasi. Tabel Krecjie menunjukkan bila jumlah populasi 100 maka sampelnya 80 , bila populasinya 1.000 maka sampelnya 278, bila populasinya 10.000 maka jumlah sampelnya 370, dan bila jumlah pupulasinya 100.000 maka sampelnya 384. Dalam penelitian ini jumlah populasinya 1.143 petani yang tergabung dalam kelompok tani dan terlibat langsung dalam kegiatan pengembangan tanaman mangrove (Dislautkan, 2013), berdasarkan tabel Krecjie maka 
sampelnya sebanyak 291 orang dilakukan sacara strata dan proporsional berdasarkan lokasi/tempat.

Analisis deskriptif yang digunakan adalah penyajian tabel dan grafik yang digunakan seperti Custom table, distribusi frekuensi (Santoso, 2003), selain itu juga untuk memberi gambaran profil dan sampel yang bermanfaat untuk mendeskripsikan variabel pemberdayaan masyarakat pesisir dan partisipasi masyarakat pesisir dalam pengembangan tanaman mangrove di Kabupaten Pati dengan menggunakan skor jawaban. Untuk mengtahui secara tepat tingkat persentase skor jawaban digunakan rumus sebagai berikut:

$$
\%=\frac{n}{N} \times 100 \%
$$

Keterangan: $\mathrm{n}=$ nilai yang diperoleh, $\mathrm{N}=$ jumlah responden, $\%=$ persentase

(Suharsimi, 2006)

Untuk mengetahui distribusi masing-masing variabel yang pengumpulannya dengan menggunakan angket, setiap indikator dari data yang telah dikumpulkan terlebih dahulu diklasifikasikan dan kemudian diberi skor. Dalam menentukan penskoran untuk masing-masing indikator dari variabel pemberdayaan masyarakat pesisir, berdasarkan pada kisi-kisi pertanyaan yang sudah disiapkan. Untuk menentukan kategori deskripsi persentase dengan jumlah item pertanyaan 15, maka diperoleh skor maksimal: 15 x $5=75$ dan skor minimal: 15 x $1=15$, kemudian dibuat tabel kategori yang disusun dengan perhitungan sebagai berikut: (a) Menetapkan skor tertinggi: 70, (b) Menetapkan skor terendah: 20, (c) Menetapkan rentang skor. Rentang diperoleh dengan cara mengurangi skor tertinggi dengan skor terendah sehingga diperoleh: 70-20 = 50. Interval kelas diperoleh dengan cara membagi rentang dengan panjang kriteria, sehingga diperoleh: $50: 5=10$. Kriteria interval untuk pemberdayaan masyarakat pesisir dapat dibuat sebagaimana Tabel 1. Sedangkan dalam menentukan skor untuk masingmasing indikator dari variabel partisipasi masyarakat pesisir, perlakuannya sama dan dimodifikasi sesuai dengan jumlah item pertanyaan.

\section{HASIL DAN PEMBAHASAN}

\section{Identitas responden}

Responden dalam penelitian ini adalah sebanyak 291 petani yang tergabung dalam kelompok tani kawasan pesisir dan terlibat langsung dalam pengembangan tanaman mangrove. Dari responden sebanyak tersebut kuesioner yang diisi oleh responden dan kembali kepada peneliti sebanyak 282 buah (96,90 \%), sudah dianggap memenuhi syarat untuk pengolahan data selanjutnya. Identitas responden secara rinci dapat dilihat pada Tabel 2.

Tabel 2 terlihat bahwa umur responden paling banyak berkisar 41-50 tahun (37,37 \% disusul umur
31-40 (24,91 \%), hal ini menunjukkan pada kisaran umur 31-50 tahun merupakan umur produktif yang mempunyai pemikiran cukup matang hubungannya dengan lingkungan dan ekonomi, sehingga wajar jika mereka mempunyai kekhawatiran akan terjadinya kerusakan lingkungan pantai akibat tidak pedulinya terhadap kelestarian pantai sebagai salah satu kegiatan ekonomi bagi mereka, oleh karena itu mereka pada umur tersebut menyadari dan dituntut untuk peduli terhadap lingkungan pantai dengan pengembangan tanaman mangrove.

Pendidikan responden sebagian besar tingkat SMA (47,69\%), kemudian disusul pendidikan SD (23,84 \%), hal ini diduga yang berpendidikan setingkat SMA merupakan generasi muda, sementara yang berpendidikan setingkat SD adalah generasi tua. Dilihat dari tingkat pendidikan dirasa sudah cukup untuk didorong mengetahui betapa pentingnya pengelolaan kawasan pesisir hubungannya dengan pengembangan tanaman mangrove. Sementara itu, pekerjaan responden sebagian besar adalah petani yang mencapai 51,60 \%, hal ini wajar karena petani yang berada dikawasan pesisir berkutat pada kegiatan dipantai sebagai petambak baik petambak garam maupun bandeng/udang dan nelayan. Oleh karena itu wajar jika mereka peduli terhadap kelestarian pantai dan berusaha untuk berpartisipasi dalam pengembangan tanaman mangrove.

\section{Wilayah Pesisir dan Tanaman Mangrove}

Berdasarkan kesepakatan umum dunia bahwa wilayah pesisir adalah suatu wilayah peralihan antara daratan dan lautan. Untuk keperluan pengelolaan batas-batas wilayah yang sejajar dengan garis pantai relatif mudah, misal seperti batas pesisir Kabupaten Pati antara ujung utara Kecamatan Dukuhseti yang berbatasan dengan Kabupaten Jepara dan ujung timur Kecamatan Batangan yang berbatasan dengan Kabupaten Rembang.

Program pengelolaan wilayah pesisir yang telah diimplementasikan mengenai batas suatu wilayah pesisir di beberapa negara antara lain: pertama, batas wilayah pesisir kearah darat pada umumnya adalah jarak secara arbitrer dari rata-rata pasut tinggi (Mean High Tide) dan batas arah laut umumnya adalah sesuai dengan batas jurisdiksi provinsi. Hal ini sesuai dengan UU No. 27 Tahun 2007 Pasal 50 ayat 2 dan 3, bahwa Gubernur berwenang memberikan Hak Pengusahaan Perairan Pesisir (HP-3) di wilayah perairan pesisir sampai dengan 12 mil laut diukur dari garis pantai kearah laut lepas dan/atau kearah perairan kepulauan, dan perairan lintas kabupaten/kota. Dan Bupati/Walikota berwenang memberikan HP-3 wilayah perairan pesisir kepada 1/3 dari wilayah kewenangan provinsi. Sementara Perda Kabupaten Pati No. 4 Tahun 2003, Pasal 5 ayat 1, menyatakan bahwa Pemerintah Daerah menetapkan kebijaksanaan pengelolaan wilayah pesisir dan laut berdasarkan peraturan perundang-undangan yang berlaku. 
Tabel 1. Pengukuran Skala Likert pada Pemberdayaan Masyarakat Pesisir

\begin{tabular}{cc}
\hline Interval persentase & Kriteria \\
\hline $20-30$ & Sangat rendah \\
$31-40$ & Rendah \\
$41-50$ & Cukup \\
$51-60$ & Tinggi \\
$61-70$ & Sangat tinggi \\
\hline
\end{tabular}

Tabel 2. Identitas Responden

\begin{tabular}{|c|c|c|c|}
\hline No & Uraian & Frekuensi & $\%$ \\
\hline \multirow[t]{7}{*}{1} & Umur (th) & & \\
\hline & $20-30$ & 22 & 7,80 \\
\hline & $31-40$ & 71 & 25,18 \\
\hline & $41-50$ & 105 & 37,23 \\
\hline & $51-60$ & 64 & 22,70 \\
\hline & $>60$ & 20 & 7,09 \\
\hline & Jumlah & 282 & 100 \\
\hline \multirow[t]{7}{*}{2} & Pendidikan & & \\
\hline & Tidak sekolah & 6 & 2,13 \\
\hline & SD & 67 & 23,76 \\
\hline & SMP & 51 & 18,08 \\
\hline & SMA & 134 & 47,52 \\
\hline & D3/S1 & 24 & 8,51 \\
\hline & Jumlah & 282 & 100 \\
\hline \multirow[t]{8}{*}{3} & Pekerjaan & & \\
\hline & Tani & 145 & 51,60 \\
\hline & Nelayan & 18 & 6,41 \\
\hline & Wiraswasta & 39 & 13,88 \\
\hline & PNS & 1 & 0,36 \\
\hline & Perangkat desa & 69 & 24,56 \\
\hline & Lain-lain & 10 & 3,56 \\
\hline & Jumlah & 282 & 100,00 \\
\hline
\end{tabular}

Sumber: Data primer, 2013

Kedua, bahwa untuk kepentingan pengelolaan batas ke arah darat dari wilayah pesisir dapat ditetapkan sebanyak dua macam, yaitu batas untuk wilayah perencanaan (planning zone) dan batas untuk wilayah pengaturan (regulation zone) atau pengelolaan keseharian (day to day management). Wilayah perencanaan sebaiknya meliputi seluruh daerah daratan atau hulu apabila terjadi kegiatan manusia (pembangunan) yang dapat menimbulkan dampak secara nyata (signifikan) terhadap lingkungan dan sumberdaya pesisir. Oleh karena itu, batas wilayah pesisir ke arah darat untuk kepentingan perencanaan (planning zone) dapat sangat jauh dari hulu. Untuk Kabupaten Pati seperti DAS Juwana, dan Ketiga, bahwa batas kearah darat dari suatu wilayah pesisir dapat berubah. Perda Kabupaten Pati No. 4 Tahun 2003 tersurat bahwa pesisir adalah daerah pertemuan antara pengaruh daratan dan pengaruh lautan. Wilayah pesisir yang digunakan sebagai obyek penelitian secara riil, meliputi luas lahan masing-masing kecamatan dan jumlah desa pesisir, secara rinci dapat dilihat pada Tabel 3. 
Tabel 3. Luas Lahan Wilayah Pesisir

\begin{tabular}{|c|c|c|c|c|c|c|c|}
\hline \multirow[t]{2}{*}{ No } & \multirow[t]{2}{*}{ Kecamatan } & \multirow{2}{*}{$\begin{array}{c}\text { Jumlah } \\
\text { Desa } \\
\end{array}$} & \multicolumn{3}{|c|}{ Luas lahan (Ha) } & \multirow[t]{2}{*}{ Jumlah } & \multirow{2}{*}{$\begin{array}{c}\text { Persentase } \\
\% \\
\end{array}$} \\
\hline & & & Sawah & Tegal & Tambak & & \\
\hline 1 & Dukuhseti & 8 & $1.534,99$ & 256,01 & $1.316,65$ & $3.107,65$ & 20,75 \\
\hline 2 & Tayu & 8 & $1.509,78$ & 85,68 & 723,34 & $2.318,80$ & 15,49 \\
\hline 3 & Margoyoso & 11 & 830,52 & 1,53 & $1.432,18$ & $2.264,23$ & 15,12 \\
\hline 4 & Trangkil & 6 & 272,94 & 0 & $1.166,96$ & $1.439,90$ & 9,62 \\
\hline 5 & Wedarijaksa & 3 & 67,13 & 0 & 737,63 & 804,76 & 5,37 \\
\hline 6 & Juwana & 10 & 428,02 & 6,38 & $2.313,89$ & $2.748,29$ & 18,35 \\
\hline \multirow[t]{2}{*}{7} & Batangan & 7 & 344,28 & 3,25 & $1.943,54$ & $2.291,07$ & 15,30 \\
\hline & Jumlah & 53 & 4.987,66 & 352,85 & $9.634,19$ & $14.974,70$ & 100 \\
\hline
\end{tabular}

Sumber: BPS Kab. Pati. 2012.

Didalam Tabel 3 menunjukkan bahwa Kecamatan yang berada di wilayah pesisir Kabupaten Pati sebanyak 7 Kecamatan dan 53 desa. Kecamatan Margoyoso merupakan kecamatan dengan jumlah desa pesisir paling banyak yaitu 11 desa (20,76\%), kemudian disusul Kecamatan Juwana dengan 10 desa (18,88\%), sementara kecamatan dengan jumlah desa pesisir paling sedikit berada di Kecamatan Wedarijaksa yaitu 3 desa (5,66\%).

Lahan sawah di wilayah pesisir seluas 4.987,66 На (35,21\%) dari luas lahan wilayah pesisir Kabupaten Pati, luas tegal 352,85 Ha (2,49\%) dan luas tambak 9.634,19 Ha (60,01\%). Tambak seluas tersebut merupakan potensi ekonomi yang sangat menjanjikan untuk dikembangkan lebih lanjut dengan mengoptimalkan potensi tambak yang sekarang ada. Pemanfaatan tambak menurut responden dikelola dengan dua cara yaitu sebagai tambak garam dan sebagai tambak budidaya terutama budidaya bandeng. Walaupun sebagian ada yang membudidayakan udang, tetapi jumlahnya masih relatif sedikit jika dibanding budidaya bandeng. Jika cuaca mendukung yaitu sekitar bulan Juli sampai September tambak dikelola dengan usaha tambak garam dan menurut responden tambak garam ini lebih menguntungkan jika dibanding dengan budidaya bandeng maupun udang. Sutrisno (2013) potensi lahan tambak garam dikawasan pesisir memiliki kekuatan untuk usaha garam yang baik dan menguntungkan, mengingat kebutuhan garam dalam negeri belum tercukupi dan untuk mencukupi kebutuhan garam tersebut masih mengimpor. Kondisi ini merupakan prospek yang perlu dimanfaatkan oleh para petambak garam termasuk petambak garam di Kabupaten Pati.

Kecamatan Juwana merupakan kecamatan yang mempunyai luas tambak paling luas yaitu 2.313,89 Ha (24,02\%). Hal ini karena masyarakat di Juwana mayoritas bergerak dalam kegiatan perikanan, baik itu perikanan tangkap maupun perikanan budidaya, sehingga penggunaan lahan lebih banyak berupa areal pertambakan dibandingkan areal persawahan. Sementara Kecamatan Tayu merupakan kecamatan yang mempunyai luas tambak paling sedikit yaitu hanya 723,34 На (7,51\%). Masyarakat di Kecamatan Tayu masih banyak yang bergerak dalam kegiatan pertanian dibandingkan kegiatan perikanan budidaya. Hal inilah yang menyebabkan areal persawahan lebih luas dibandingkan areal pertambakan.

Sementara itu, tanaman bakau (mangrove) adalah ekosistem yang berupa hamparan lahan pantai yang berisi sumberdaya alam hayati dengan kekhasan atau ciri khas hidup di wilayah pantai. Wilayah pantai berhutan bakau (mangrove) berfungsi memberi perlindungan kepada perikehidupan pantai dan lautan (Perda Kab. Pati No. 4 Tahun 2003).

Tanaman mangrove dan ekosistem mangrove cukup tahan terhadap berbagai gangguan dan tekanan lingkungan. Namun demikian mangrove tersebut sangat peka terhadap pengendapan atau sedimentasi, tinggi rata-rata permukaan air, pencucian serta tumpahan minyak. Keadaan ini mengakibatkan penurunan kadar oksigen dengan cepat untuk kebutuhan respirasi dan pada akhirnya dapat menyebabkan kematian mangrove. Perubahan faktor-faktor yang mengontrol pola salinitas substrat dapat menyebabkan perubahan komposisi spesies, dan salinitas yang lebih dari 90 ppm dapat mengakibatkan kematian biota dalam jumlah besar. Perubahan salinitas dapat diakibatkan oleh perubahan siklus hidrologi, aliran air tawar dan pencucian terus menerus seperti kegiatan pengerukan.

Agustono (1996) menyatakan bahwa faktor utama kerusakan tanaman mangrove di wilayah pesisir adalah miskinnya masyarakat di daerah tersebut. Kerusakan tanaman mangrove di pantura Provinsi Jawa Tengah telah mencapai 96,5\% (rusak berat $62,5 \%$ dan rusak ringan $32 \%$ ). Sementara kerusakan hutan mangrove di wilayah pantai Kabupaten Pati mencapai 72,20 Ha (22,10 \%) (Dislautkan Kab. Pati, 2013). Kerusakan tanaman mangrove ini berakibat menurunnya produktivitas 
tambak, karena tanaman mangrove berfungsi sebagai tempat pemijahan, tempat pengasuhan dan tempat makanan bagi biota laut termasuk ikan, udang, dan kepiting. Peran utama masyarakat pesisir dalam pengelolaan tanaman mangrove sangat menentukan keberhasilan kelestarian wilayah mangrove. Ditegaskan pula bahwa masyarakat yang tergabung dalam kelembagaan baik secara lokal, regional maupun nasional akan lebih mendorong terciptanya wilayah tanaman mangrove. Namun demikian, masih ada oknum yang merusak tanaman mangrove secara ilegal hanya karena untuk kepentingan pribadi dalam rangka memperluas areal tambak. Hal ini sangat disesalkan, sebagaimana penuturan Bapak Sukarno Ketua Forum Koordinasi Pengelolaan Sumberdaya Pesisir dan Laut Kabupaten Pati (FKPSPL).

\section{Pemberdayaan Masyarakat}

Rasyid (1996) menyatakan bahwa pemberdayaan merupakan tugas pokok dari pemerintah, disamping dua tugas lainnya yakni pelayanan/service dan pengaturan/regulatory. Tugas pemberdayaan pada hakikatnya diarahkan pada terwujudnya sebuah komunitas masyarakat yang berdaya dan mandiri yang mampu berperan sebagai mitra dari pemerintah dalam pembangunan. Dengan pengertian lain, yaitu sebuah masyarakat yang mampu berperan sebagai subyek dalam pembangunan, tidak sebagai obyek dari pembangunan seperti yang telah terjadi selama ini. Pemberdayaan masyarakat bukan membuat masyarakat menjadi makin tergantung pada berbagai program pemberian (charity). Pendekatan utama dalam konsep pemberdayaan adalah bahwa masyarakat tidak dijadikan obyek dari berbagai proyek pembangunan tetapi merupakan subyek dari upaya pembangunannya sendiri (Sumodiningrat, 1999). Sementara itu pemberdayaan masyarakat pesisir ditujukan untuk masyarakat diwilayah pesisir dalam pengembangan tanaman mangrove di Kabupaten Pati.

Hasil penelitian menunjukkan bahwa peranan pemerintah terhadap pemberdayaan masyarakat pesisir dalam pengembangan tanaman mangrove di Kabupaten Pati dievaluasi dengan menggunakan variasi nilai yang terbagi dalam 5 (lima) kategori dengan interval nilai yaitu: sangat rendah $(20,00-$ $30,00)$, rendah $(30,01-40,00)$, cukup $(40,01-50,00)$, tinggi (50,01-60,00), dan sangat tinggi (60,0170,00). Sementara itu untuk indikator penyuluhan, sosialisasi, pembinaan dan studi banding dievaluasi dengan menggunakan variasi nilai yang terbagi dalam 5 (lima) kategori dengan beberapa modifikasi. Hasil analisis peran pemerintah terhadap pemberdayaan masyarakat pesisir dalam pengembangan tanaman mangrove di Kabupaten Pati secara rinci dapat dilihat pada Tabel 4.

Tabel 4 tersebut menunjukkan bahwa skor rata-rata dari semua indikator dan variabel pemberdayaan masyarakat pesisir: pertama, penyuluhan memperoleh skor 17,34 termasuk katagori tinggi, artinya peran pemerintah dalam penyuluhan berkaitan dengan pengembangan tanaman mangrove sudah dianggap baik dan efektif sehingga masyarakat pesisir diharapkan dapat mengembangkan tanaman mangrove untuk menjaga kelestarian pantai. Hal ini sesuai dengan pendapat Kartasaputra (1994) bahwa tujuan penyuluhan jangka pendek untuk menumbuhkan perubahanperubahan yang lebih terarah dalam aktivitas usahatani dipedesaan, perubahan-perubahan mana hendaknya menyangkut: tingkat pengetahuan, kecakapan atau kemampuan sikap dan motif tindakan petani. Namun demikian masih ada 9,22 \% masyarakat pesisir yang masuk katagori sangat rendah, hal ini juga wajar karena diduga mereka kurang interaktif dengan masyarakat lain atau berpandangan lain bahwa urusan kelestarian pantai adalah urusan pemerintah, sehingga mereka tidak perlu "repot-repot" ikut terlibat didalamnya. Mestinya pendapat seperti itu tidak perlu terjadi karena lingkungan pantai sebagai salah satu kesatuan kegiatan ekonomi adalah milik bersama yang harus dikelola dan dijaga bersama.

Kedua, peran pemerintah dalam sosialisasi tentang pengembangan tanaman mangrove termasuk katagori cukup dengan skor 11,82, hal ini menunjukkan pemerintah masih perlu terus menerus mengadakan sosialisasi, seperti pemasangan spanduk, baliho, papan peringatan, pertemuan melalui RT/RW disertai dengan tindakan dan bantuan berupa bibit mangrove agar masyarakat pesisir dapat tertarik dan melaksanakan anjuran dalam sosialisasi tersebut. Terdapat 28,37 \% responden masuk dalam katagori tinggi, artinya mereka sudah menyadari bahwa peran pemerintah dalam sosialisasi sudah dianggap cukup baik oleh karena itu perlu dorongan untuk implementasinya. Sementara itu masih terdapat $12,06 \%$ responden yang termasuk katagori rendah, hal ini diduga mereka masih apatis terhadap pengembangan tanaman mangrove untuk kelestarian pantai, mereka beranggapan bahwa semua itu adalah urusan pemerintah, oleh karena itu sosialisasi pengembangan tanaman mangrove perlu diintensifkan agar mereka tumbuh kesadarannya mengingat kelestarian pantai itu penting. Hasil ini sesuai dengan penelitian (Supriyanto, 2004) yang menyatakan bahwa kegiatan sosialisasi sebagai upaya peningkatan pengetahuan dianggap sebagai suatu keharusan yang perlu diikuti semua masyarakat ditengah menurunnya sumberdaya perikanan tangkap akibat rusaknya ekosistem payau berupa tanaman mangrove.

Ketiga, peran pemerintah dalam pembinaan tentang pengembangan tanaman mangrove hubungannya dengan kelestarian pantai termasuk dalam katagori tinggi dengan skor 14,67. Artinya pembinaan yang dilakukan oleh pemerintah melalui dinas/instansi terkait sudah cukup efektif dan perlu 
Tabel 4. Pemberdayaan Masyarakat Pesisir

\begin{tabular}{|c|c|c|c|c|c|}
\hline $\begin{array}{c}\text { Indikator dan } \\
\text { Variabel }\end{array}$ & Interval & Kriteria & Frek & $\%$ & $\begin{array}{c}\text { Skor } \\
\text { rata-rata }\end{array}$ \\
\hline \multirow{5}{*}{ Penyuluhan } & $07,00-10,40$ & Sangat rendah & 26 & 9,22 & \\
\hline & $10,41-13,80$ & Rendah & 14 & 4,96 & \\
\hline & $13,81-17,20$ & Cukup & 70 & 24,82 & $4.889 / 282=$ \\
\hline & $17,21-20,60$ & Tinggi & 145 & 51,42 & 17,34 \\
\hline & $20,61-24,00$ & Sangat tinggi & 27 & 9,57 & \\
\hline \multirow{7}{*}{ Sosialisasi } & & Jumlah & 282 & 100,00 & \\
\hline & $06,00-08,60$ & Sangat rendah & 34 & 12,06 & \\
\hline & $08,69-11,20$ & Rendah & 91 & 32,27 & $3.332 / 282=$ \\
\hline & $11,21-13,88$ & Cukup & 67 & 23,76 & 11,82 \\
\hline & $13,89-16,40$ & Tinggi & 80 & 28,37 & \\
\hline & $16,41-19,00$ & Sangat tinggi & 10 & 3,55 & \\
\hline & & Jumlah & 282 & 100,00 & \\
\hline \multirow{5}{*}{ Pembinaan } & $06,00-8,60$ & Sangat rendah & 18 & 6,38 & \\
\hline & $08,69-11,20$ & Rendah & 14 & 4,96 & \\
\hline & $11,21-13,80$ & Cukup & 31 & 10,99 & $4.136 / 282=$ \\
\hline & $13,81-16,40$ & Tinggi & 181 & 64,18 & 14,67 \\
\hline & $16,41-19,00$ & Sangat tinggi & 38 & 13,48 & \\
\hline \multirow{7}{*}{ Studi banding } & & Jumlah & 282 & 100,00 & \\
\hline & $03,00-04,20$ & Sangat rendah & 104 & 36,88 & \\
\hline & $04,21-05,40$ & Rendah & 3 & 1,06 & $1.725 / 282=$ \\
\hline & $05,41-06,60$ & Cukup & 25 & 8,87 & 6,12 \\
\hline & $06,61-07,80$ & Tinggi & 17 & 6,03 & \\
\hline & $07,81-09,00$ & Sangat tinggi & 133 & 47,16 & \\
\hline & & Jumlah & 282 & 100,00 & \\
\hline & $20,00-30,00$ & Sangat rendah & 13 & 4,61 & \\
\hline Pemberdayaan & $30,01-40,00$ & Rendah & 24 & 8,51 & $14.082 / 282=$ \\
\hline Masyarakat & $40,01-50,00$ & Cukup & 99 & 35,11 & 49,94 \\
\hline \multirow[t]{3}{*}{ Pesisir } & $50,01-60,00$ & Tinggi & 120 & 42,55 & \\
\hline & $60,01-70,00$ & Sangat tinggi & 26 & 9,22 & \\
\hline & & Jumlah & 282 & 100,00 & \\
\hline
\end{tabular}

Sumber: Analisis scoring, 2013

konsistensi implementasi program serta pembinaan dalam pengembangan tanaman mangrove. Senada hasil penelitian Supriyanto (2004), masyarakat menganggap pembinaan yang dilakukan dinas/instansi terkait bermanfaat secara langsung dan ditindaklanjuti dengan kegiatan fisik dilapangan seperti: rehabilitasi lahan tambak yang rusak berikut bibit pohon dan benih ikan, pakan dan batuan pemeliharaan. Masih terdapat 6,38 \% responden masuk dalam katagori sangat rendah dalam menerima pembinaan, hal ini perlu mendapatkan perhatian lebih agar mereka dapat menerima dengan baik dalam pembinaan pengembangan tanaman mangrove untuk kelestarian pantai.

Keempat, pelaksanaan studibanding kedaerah lain yang lebih berhasil dalam mengelola tanaman mangrove hubungannya dengan kelestarian pantai masih perlu diupayakan karena studibanding bisa memotivasi masyarakat pesisir untuk mengadopsi kondisi yang sudah berhasil, memperoleh skor 6,12 termasuk dalam katagori cukup. Terdapat $47,16 \%$ responden masuk dalam katagori sangat tinggi, artinya mereka berpendapat bahwa studi banding masih perlu dilakukan agar 
mereka termotivasi untuk mencontoh atau mengadopsi keberhasilan daerah lain dalam mengelola kelestarian pantai dengan pengembangan tanaman mangrove. Hasil penelitian Supriyanto (2004) menunjukkan bahwa kegiatan studi banding diharapkan selepas mengikuti kunjungan lapangan (studi banding) masyarakat dapat mengadopsi model pengelolaan hutan mangrove secara berkelanjutan pada lokasi kunjungan.

Kelima, pemberdayaan masyarakat pesisir yang dilakukan oleh pemerintah melalui penyuluhan, sosialisasi, pembinaan dan studibanding termasuk dalam katagori cukup baik dengan skor 49,94. Hal ini masih perlu ditingkatkan pemberdayaannya, mengingat betapa penting pengembangan tanaman mangrove untuk kelestarian pantai. Namun demikian ada 42,55 \% responden masuk dalam katagori tinggi sehingga mereka perlu didorong untuk mengembangkan tanaman mangrove. Penelitian Parawansa (2007) memperkuat penelitian ini bahwa prioritas kebijakan pengelolaan hutan mangrove Teluk Jakarta secara berkelanjutan berdasarkan aspirasi stakeholders secara berturut-turut adalah pemberdayaan masyarakat, penerapan teknologi dan pengelolaan terpadu.

\section{Partisipasi Masyarakat}

$\begin{array}{rrrr}\text { Mulyana } & \text { (1996) } & \text { menyatakan } & \text { bahwa } \\ \text { partisipasi/peran } & \text { serta } & \text { masyarakat } & \text { dapat }\end{array}$
didefinisikan: (1) adanya subyek yang berinteraksi yaitu individu yang berada dalam suatu unit masyarakat (kelompok), organisasi perekonomian, pemerintah dan bangsa. Masing-masing memiliki keleluasaan untuk mengambil keputusan sendirisendiri tetapi terikat dalam suatu ikatan solidaritas tertentu untuk mewujudkan kepentingan atau rencana bersama; (2) adanya kerelaan dan kesadaran dari individu untuk menjalankan peran yang diberikan oleh kelompok secara iklas. Keikutsertaan tidak atas dasar kekuasaan pemimpin (formal); dan (3) partisipasi berkonotasi kepada keterlibatan anggota perorangan dalam proses pengelolaan suatu kegiatan (pengambilan keputusan bersama, pengarahan, sumberdaya, pengawasan dan penyesuaian).

Hasil penelitian terhadap partisipasi masyarakat pesisir dalam pengembangan tanaman mangrove di Kabupaten Pati terdiri dari 4 indikator yaitu perencanaan, pembibitan, penanaman, dan pemeliharaan. Variabel partisipasi masyarakat dievaluasi dengan menggunakan variasi nilai yang terbagi dalam 5 (lima) katagori yaitu: sangat rendah (15 - 24), rendah (25 - 33), cukup (34 - 42), tinggi (43 - 51), dan sangat tinggi (52 - 60). Sementara itu untuk indikator perencanaan, pembibitan, penanaman, dan pemeliharaan dievaluasi dengan menggunakan variasi nilai yang terbagi dalam 5 (lima) katagori dengan beberapa modivikasi. Hasil analisis partisipasi masyarakat pesisir dalam pengembangan tanaman mangrove di Kabupaten Pati secara rinci dapat dilihat pada Tabel 5.
Dapat dilihat pada Tabel 5 bahwa skor ratarata dari semua indikator dan variabel partisipasi masyarakat pesisir: pertama, proses perencanaan masih perlu meningkatkan partisipasi masyarakat pesisir agar mereka merasa terlibat dalam perencanaan pengembangan tanaman mangrove, memperoleh skor rata-rata 13,41 termasuk katagori cukup. Namun demikian terdapat 51,06 \% responden masuk dalam katagori tinggi, artinya proses perencanaan sebagian besar melibatkan partisipasi masyarakat pesisir karena dalam pengembangan selanjutnya peranan mereka sangat besar sehingga partisipasinya perlu dilibatkan dalam proses perencanaan pengembangan tanaman mangrove. Hasil penelitian yang lain menunjukkan bahwa proses perencanaan yang baik perlu melibatkan masyarakat yang menerima dampak secara langsung. UU No 25/2004, perencanaan adalah suatu proses untuk menentukan tindakan masa depan yang tepat, melalui urutan pilihan, dengan memperhitungkan sumber daya yang tersedia. Perencanaan, dapat memberikan tuntunan bagi pencapaian tujuan organisasi yang telah ditetapkan menjadi lebih efisien dan efektif, karena perencanaan meliputi keputusan tentang waktu yang akan datang, apa yang akan dilakukan, bila akan dilakukan, dan siapa yang akan melakukan.

Kedua, partisipasi masyarakat pesisir dalam pembibitan mangrove memperoleh skor rata-rata 10,67 termasuk katagori cukup. Artinya partisipasi masyarakat pesisir adalah cukup baik dan peduli terhadap pembibitan mangrove, karena mereka menganggap pembibitan mangrove adalah salah satu kegiatan untuk pengembangan tanaman mangrove yang mempunyai manfaat besar terhadap pelestarian pantai sehingga masyarakat pesisir merasa peduli terhadap kegiatan yang satu ini. Terdapat 8,87 \% responden yang masih sangat rendah kepeduliannya/partisipasinya terhadap pembibitan mangrove, hal ini diduga mereka masih merasa apatis karena menganggap pembibitan mangrove merupakan tugas pemerintah untuk menyediakan. Pendapat seperti itu sebenarnya tidak perlu terjadi, oleh karena itu peranan penyuluhan dan sosialisasi yang gencar dan efektif perlu dilakukan agar mereka mengetahui dan tertarik betapa pentingnya pengembangan tanaman mangrove dalam peletarian pantai.

Ketiga, partisipasi masyarakat pesisir dalam penanaman mangrove sudah cukup baik dengan skor rata-rata 8,94. Menurut mereka bibit yang sudah tersedia baik oleh swadaya masyarakat maupun bantuan pemerintah atau bantuan swasta, perlu segera ditanam sesuai perencanaan dan baku teknis penanaman sehingga pengembangan tanaman mangrove dalam rangka pelestarian pantai dapat berjalan dengan baik. Partisipasi masyarakat pesisir dalam penanaman mangrove yang mengacu pada teknis penanaman dari hasil penyuluhan dan sosialisasi dibawah bimbingan dinas/instansi terkait 
Tabel 5. Partisipasi Masyarakat Pesisir

\begin{tabular}{|c|c|c|c|c|c|}
\hline $\begin{array}{c}\text { Sub variabel dan } \\
\text { variabel }\end{array}$ & Interval & Kriteria & Frekuensi & Persentase & $\begin{array}{c}\text { Skor } \\
\text { rata-rata }\end{array}$ \\
\hline Sub vaiabel & $6,0-8,6$ & Sangat rendah & 34 & 12,06 & \\
\hline \multirow[t]{5}{*}{ Perencanaan } & $8,7-11,2$ & Rendah & 32 & 11,35 & $3782 / 282=$ \\
\hline & $11,3-13,8$ & Cukup & 55 & 19,50 & 13,41 \\
\hline & $13,9-16,4$ & Tinggi & 144 & 51,06 & \\
\hline & $16,5-19,0$ & Sangat tinggi & 17 & 6,03 & \\
\hline & & Jumlah & 282 & 100 & \\
\hline Sub variabel & $5,0-6,8$ & Sangat rendah & 25 & 8,87 & \\
\hline \multirow[t]{5}{*}{ Pembibitan } & $6,9-8,6$ & Rendah & 40 & 14,18 & $2687 / 282=$ \\
\hline & $8,7-10,4$ & Cukup & 127 & 45,04 & 9,53 \\
\hline & $10,5-12,2$ & Tinggi & 72 & 25,53 & \\
\hline & $12,3-14,0$ & Sangat tinggi & 18 & 6,38 & \\
\hline & & Jumlah & 282 & 100 & \\
\hline Sub varaibel & $5,0-6,8$ & Sangat rendah & 28 & 9,93 & \\
\hline \multirow[t]{5}{*}{ Penanaman } & $6,9-8,6$ & Rendah & 64 & 22,70 & $2522 / 282=$ \\
\hline & $8,7-10,4$ & Cukup & 124 & 43,97 & 8,94 \\
\hline & $10,5-12,2$ & Tinggi & 55 & 19,50 & \\
\hline & $12,3-14,0$ & Sangat tinggi & 11 & 3,90 & \\
\hline & & Jumlah & 282 & 100 & \\
\hline Sub varaibel & $5,0-6,8$ & Sangat rendah & 7 & 2,48 & \\
\hline \multirow[t]{5}{*}{ Pemeliharaan } & $6,9-8,6$ & Rendah & 26 & 9,22 & $2799 / 282=$ \\
\hline & $8,7-10,4$ & Cukup & 128 & 45,39 & 9,93 \\
\hline & $10,5-12,2$ & Tinggi & 93 & 32,98 & \\
\hline & $12,3-14,0$ & Sangat tinggi & 28 & 9,93 & \\
\hline & & Jumlah & 282 & 100 & \\
\hline Variabel & $15-24$ & Sangat rendah & 2 & 0,71 & \\
\hline Partisipasi & $25-33$ & Rendah & 28 & 9,93 & $11790 / 282=$ \\
\hline masyarakat & $34-42$ & Cukup & 119 & 42,20 & 41,81 \\
\hline \multirow[t]{3}{*}{ pesisir } & $43-51$ & Tinggi & 115 & 40,78 & \\
\hline & $52-60$ & Sangat tinggi & 18 & 6,38 & \\
\hline & & Jumlah & 282 & 100 & \\
\hline
\end{tabular}

Sumber: Analisis scoring, 2013

dan penyuluh menjadikan mereka antusias untuk terlibat dalam penanaman. Namun demikian masih ada 9,93\% responden sangat rendah partisipasinya terhadap penanaman mangrove, hal ini perlu diantisipasi dengan pendekatan penyuluhan dan sosialisasi yang gencar dan terus menerus agar mereka mau merubah sikapnya untuk berpartisipasi dalam penanaman mangrove.

Keempat, partisipasi masyarakat pesisir terhadap pemeliharaan tanaman mangrove cukup baik dengan memperoleh skor rata-rata 9,93. Untuk pertumbuhan dan perkembangan tanaman mangrove, perlu pemeliharaan dan perawatan sesuai baku teknis tanaman mangrove dibawah bimbingan teknis penyuluh agar tanaman dapat tumbuh dan berkembang dengan baik sehingga kelestarian pantai dapat tercapai. Masih ditemukan 2,48 \% responden yang sangat rendah partisipasinya terhadap pemeliharaan tanaman mangrove, hal ini masih tergolong wajar tetapi perlu didorong untuk ikut serta dalam partisipasi pemeliharaan tanaman mangrove yang sudah dikembangkan.

Kelima, partisipasi masyarakat pesisir yang terdiri dari indikator tersebut (perencanaan, pembibitan, penanaman, dan pemeliharaan) memperoleh skor rata-rata 41,81 termasuk katagori 
cukup. Artinya masyarakat pesisir sudah mulai peduli terhadap pengembangan tanaman mangrove. Mereka menganggap bahwa lingkungan pantai yang lestari akibat pengembangan tanaman mangrove merupakan keuntungan bagi kegiatan ekonomi, sehingga mereka menyadari betapa pentingnya menjaga kelestarian pantai. Masih ada 0,71 \% responden partisipasinya masih sangat rendah, oleh karena itu perlu dorongan, penyuluhan dan sosialisasi yang terus menerus agar mereka timbul kesadaran betapa pentingnya kelestarian lingkungan pantai untuk kegiatan ekonomi.

\section{KESIMPULAN}

1. Peranan pemerintah dalam pemberdayaan masyarakat pesisir memperoleh skor rata-rata 49,94 termasuk pada katagori cukup, artinya pemberdayaan masyarakat pesisir yang dilakukan oleh pemerintah melalui penyuluhan, sosialisasi, pembinaan dan studi banding termasuk dalam katagori cukup baik.

2. Partisipasi masyarakat pesisir melalui perencanaan, pembibitan, penanaman, dan pemeliharaan dalam pengembangan tanaman mangrove memperoleh skor rata-rata 41,81 termasuk katagori cukup, artinya masyarakat pesisir sudah mulai peduli terhadap pengembangan tanaman mangrove dalam pelestarian pantai. Karena mereka menganggap bahwa lingkungan pantai yang lestari merupakan keuntungan bagi kegiatan ekonomi, sehingga mereka menyadari betapa pentingnya pengembangan tanaman mangrove dalam menjaga kelestarian pantai.

Saran yang disampaikan pada artikel ini adalah:

1. Peran pemerintah terhadap pemberdayaan masyarakat pesisir dalam pengembangan tanaman mangrove untuk melestarikan pantai termasuk katagori cukup, oleh karena itu pemerintah (Dislautkan, Dishutbun, BLH, BAPPEDA dan Instansi tarkait lainnya), perlu meningkatkan dan memberdayaan masyarakat pesisir dalam melestarikan pantai melalui penyuluhan, sosialisasi, dan bantuan bibit mangrove yang berkualitas.

2. Partisipasi masyarakat pesisir dalam penanaman mangrove untuk melestarikan pantai termasuk katagori cukup, oleh karena itu peran pemerintah daerah (Dislautkan, Dishutbun, BLH, BAPPEDA dan Instansi tarkait lainnya), perlu ditingkatkan dalam mendorong partisipasi masyarakat pesisir melalui penyuluhan, sosialisasi, dan bantuan bibit mangrove yang berkualitas.

\section{Daftar Pustaka}

Agustono, 1996. Nilai Ekonomi Hutan Mangrove Bagi Masyarakat (Studi kasus dimuara Cimanuk Indramayu ). Tesis PPs IPB, Bogor.
BPS. Kab. Pati. 2012. Pati dalam Angka. Pati

Departemen Kehutanan Republik Indonesia. 2006. Inventarisasi dan Identifikasi Mangrove Wilayah Balai Pengelolaan DAS Pemali Jratun Propinsi Jawa Tengah, Direktorat jenderal Rehabilitasi Lahan dan Perhutanan Sosial, Balai Pengelolaan Daerah Aliran Sungai PemaliJratun Propinsi Jawa Tengah. Semarang.

Dislautkan Kab. Pati. 2013. Kondisi tanaman mangrove. Laporan kegiatan. Pati.

Kartasapoetra,A.G. 1994. Tekonologi Penyuluhan Pertanian. Bumi Aksara. Jakarta.

Kusmana, C. 1995. Habitat Hutan Mangrove dan Biota. Laboratorium Ekologi Hutan. Fakultas Kehutanan. Bogor : Institut Pertanian Bogor.

Manaf, M. 2013. Ekosistem Pesisir Dan Pengolahannya.

http://abdulkadirk460.blogspot.com/2013/05/ek osistem-pesisir-dan-pengelolaanya.html. Diakses tanggal 10 September 2013.

Mulyana, Slamet. 1996. Peranserta Masyarakat dan Upaya Pengendalian Kerusakan Ekosistem Kawasan Pesisir. Makalah disampaikan pada pelatihan penanganan pengendalian dan pengelolaan kawasan pesisir. Pantai dan laut. Pemda Tingkat I Jawa Tengah. Tanggal 21-26 Oktober 1996.

Nasir. 2003. Metode Penelitian. Ghalia Indonesia. Jakarta.

Nurmalasari, Y. 2001. Analisis Pengelolaan Wilayah Pesisr Berbasis Masyarakat. http://www.stmikim.ac.id/userfiles/jurnal\%20yessi.pdf. Diakses tanggal 10 Februari 2013.

Parawansa, Indar. 2007. Pengembangan Kebijakan Pembangunan Daerah dalam Pengelolaan Hutan Mangrove di Teluk Jakarta secara Berkelanjutan. Disertasi. Sekolah Pascasarjana IPB. Bogor

Rasyid, Ryaas M. 1996. Makna Pemerintahan, Tinjauan dari segi Etika dan Kepemimpinan. Yasrif Watampua, Jakarta.

Santoso, Singgih. 2003. SPSS Versi 10. Mengolah Data Statistik Secara Profesional. Elex Media Komputindo. Jakarta.

Sembiring SN, Husbaini, F. 1999. Kajian Hukum dan Kebijakan Pengelolaan Kawasan Konservasi di Indonesia. Lembaga Pengembangan Hukum Lingkungan (ICEL) NRMP. Jakarta.

Sugijono. 1999. Metode Penelitian Administrasi, Alfabeta. Bandung.

Suharsimi, Arikunto. 2006. Prosedur Penelitian Suatu Pendekatan Praktek. Rineka Cipta. Jakarta.

Sumodiningrat, G. 1999. Pemberdayaan Masyarakat dan Jaring Pengaman Sosial. Gramedia. Jakarta.

Supriyanto. 2004. Hubungan Pemberdayaan dan Partisipasi masyarakat dalam rehabilitasi Hutan Mangrove di Desa Jetis Kecamatan Nusawungu. Kabupaten Cilacap. Tesis. PP Undip. Semarang.

Sutrisno. 2013. Analisis Lingkungan Internal dan Eksternal Peningkatan Produksi Garam Rakyat (Studi di Kecamatan Batangan Kabupaten Pati). Jurnal Litbang. Vol IX No 2 hal 107-120 
UU RI No 25 Tahun 2004 tentang Sistem Perencanaan Pembangunan Nasional.

UU RI No 27 Tahun 2007 tentang Pengelolaan Wilayah Pesisir dan Pulau-pulau Kecil.
Perda Kab. Pati Nomor 4 Tahun 2003 Tentang Pengelolaan Wilayah Pesisir Dan Laut. 